\title{
ВЛИЯНИЕ ПАНДЕМИИ НА ИНФОРМАЦИОННУЮ ТРАНСФОРМАЦИЮ МЕСТНОГО САМОУПРАВЛЕНИЯ
}

Процессы информатизации общества в последнее десятилетие продолжают получать свое всё более обширное развитие. Сегодня практически все сферы жизни человека так или иначе связаны с информационной средой. Этот процесс глобальный и он охватывает все развитые и развивающиеся страны мира, Россию эти изменения тоже не обходят стороной $[6,14]$. Меняется при этом не только социальное взаимодействие, но и специфика политического участия на всех уровнях власти. Очередным этапом и фактором цифровой модернизации социума и системы политической власти можно считать пандемию коронавируса COVID-19. Так, в условиях административного ограничения физических контактов информационная трансформация ускоряется и полностью раскрывает свой потенциал в рамках взаимодействия между политическими субъектами и группами.

Цифровая среда становится основным инструментом коммуникации, происходят обширные изменения специфики образовательного процесса, сферы услуг и трудовой деятельности. В России эти процессы также находят свое отражение, в нашей стране сегодня фиксируется усиленный рост, особенно за период пандемии, пользователей виртуальных сетей [7].

Нам еще только предстоит осмыслить те трансформационные процессы, которые произошли в связи распространением коронавирусной инфекции, но уже сейчас некоторые авторы отмечают, что ускоренная цифровая трансофрмация создала практически новую социальную и политическую повестку. Последствия которой - это необходимость корректировки и пересмотра политических стратегий и подходов на всех уровнях, включая не только национальный, но и глобальный. Более того, звучат предположения о необходимости пересмотра параметров общественного договора для его адаптации к новому этапу мирового информационно-социального развития [8, 37].

Кроме того, сегодня усиленный процесс виртуализации досуга и трудовой деятельности людей влечет за собой рост цифровых компетенций граждан, что открывает дополнительные возможности при реализации так называемого «Электронного участия». Этот комплекс методов и инструментов, обеспечивающих электронное взаимодействие граждан 
и органов власти при увеличении цифровых навыков граждан позволит более качественно учитывать мнение граждан не только на государственном, региональном, но и на муниципальном уровне. Общепринято, что главным показателем эффективности электронного участия является оперативность и качество реагирования органов власти и подведомственных организаций на обращения граждан, в т.ч. не относящихся напрямую к политическому процессу $[9,60]$. Что на практике слабо реализуемо, так как не все слои населения, в том числе в силу возраста, имеют необходимые компетенции и возможности для такого участия. Пандемия же диктует необходимость дальнейшей трансформации и адаптации к новым условиям всех категорий граждан.

В тоже время пандемия, способствующая информационной трансформации, усиливает и наиболее релевантные тренды в структуре медиа-потребления. Очевидным является тот факт, что главный тренд это снижение эффективности традиционных СМИ и ускоренная смена фокуса социального интереса на соцмедиа, что ведёт к возникновению политических рисков, связанных с ослаблением главных инструментов формирования политического и социального поля. Так, молодая часть населения России сегодня практически абсолютно находится в виртуальном медиа-пространстве, в частности социальных медиа [10, 144].

Таким образом, процессы цифровой трансформации сегодня, очевидно, получили новый этап развития в связи с распространением коронавируса COVID-19 и последующими реакциями, как со стороны властей, так и со стороны населения, которое подстраиваясь под административные ограничения, усилило существующие тренды.

Касательно трансформации системы местного самоуправления и специфики участия населения в деятельности органов МСУ при новых условиях, можно отметить ряд существенных изменений в связи с ускоренной информатизацией. Так, на примере органов местной власти Уфы, в частности деятельности Совета ГО г. Уфа РБ можно зафиксировать соответствующие изменения, вызванные факторами пандемии, в нормативно-правовых актах.

В частности, одна из основных форм прямого участия граждан в местном самоуправлении - это публичные слушания. Для граждан это возможность принять участие в формировании нормативно-правовых актов муниципалитета. Для муниципалитета - это возможность получить мнение жителей муниципального образования. Жители принимают, в соответствии с действующим российским законодательством, непосредственное участие в слушаниях и обсуждают вопросы местного значения. Кроме того, в соответствии с федеральным законодательством по некоторым вопросам муниципалитеты не просто могут, но и обязаны проводить публичные слушания [1]. 
Пандемия внесла свои коррективы, и теперь данный инструмент демонстрирует нам процесс информационной трансформации местного самоуправления. В положении Совета ГО г. Уфа РБ о публичных слушаниях в городском округе город Уфа были внесены изменения. Был добавлен соответствующий раздел «5. Особенности проведения публичных слушаний при введении на территории Республики Башкортостан и городского», который позволил проводить при определенных условиях данные слушания в заочном формате [3].

Конечно, это не отменяет проведение слушаний в очном формате и возможность гражданина направить предложения в письменной форме, без использования информационных технологий. Тем не менее предусмотрена возможность участия в слушаниях посредством информационных средств, что предполагает при определенных условиях и в перспективе переход к новой системе проведения публичных слушаний.

Это подтверждает и ряд других изменений. Например, в 2020 году произошли изменения и в Уставе ГО г. Уфа РБ. Прежде всего эти изменения коснулись публикации муниципальных правовых актов в средствах массовой информации. С момента принятия решения, уфимские муниципальные правовые акты, помимо размещения в печатных СМИ, будут публиковаться в официальных сетевых изданиях данных СМИ в течение 7 дней со дня их подписания. Главное изменение, демонстрирующие процессы информационной трансформации местного самоуправления, заключается в том, что в случае размещения полного текста муниципального правового акта в официальном сетевом издании, объёмные графические и табличные приложения к нему в печатном издании могут не приводиться [4].

Получается, что полный объем данных получат только те граждане, которые, как минимум, имеют соответствующий электронный доступ и компетенции поиска и сбора информации в сетевых изданиях. Кроме того, официальным обнародованием Устава ГО г. Уфа РБ, внесение в него изменений, а также муниципальных правовых актов, в случае принятия изменений, будет являться публикация их текстов на портале Министерства юстиции Российской Федерации «Нормативные правовые акты в Российской Федерации» - pravo.minjust.ru, право-минюст.рф. Данные изменения были внесены на фоне введения административных ограничений в связи с распространением коронавирусной инфекции, что опять же, представляет собой яркий пример изменений, вызванных не только изменениями на федеральном уровне, но и пандемией, необходимостью донесения необходимой информации до граждан в условиях административных ограничений.

Как уже отмечалось, изменения коснулись трудовой деятельности россиян, но, следует подчеркнуть, преобразования произошли 
и в деятельности депутатских корпусов муниципальных образований. Рассмотрим подобные изменения опять же на примере Совета ГО г. Уфа РБ. Так, в июне 2021 года были внесены изменения в Регламент Совета ГО г. Уфа РБ. Теперь городской Совет Уфы, как и его Президиум, постоянные комиссии в период введения на территории городского режима повышенной готовности и иных ограничительных мер могут осуществлять свою деятельность дистанционно. В новом регламенте предусмотрено использование средств ИКТ, видеоконференцсвязи и специальных программ, которые дают возможность коммуницировать участникам заседания онлайн [5]. На данный момент, у депутатов фактически есть возможность перенести основную часть своей работы в электронный формат. Такие изменения существенны для органов местного самоуправления и вызваны, можно сказать, форсированы, исключительно развернувшиеся в России пандемией.

Был ряд других решений Совета ГО г. Уфа РБ, вызванных пандемией, но они несли исключительно социально-экономическую направленность, а здесь же мы имеем перестройку формата сегодняшнего и возможно будущего взаимодействия жителей и органов МСУ. Можно утверждать, что из-за пандемии произошел существенный сдвиг рамок дискурса в данном направлении.

Отметим, что Совет ГО г. Уфа РБ здесь далеко не один в этом процессе, ряд муниципалитетов из других регионов России идёт по тому же пути. Вносятся соответствующие изменения. Например, подобные изменения коснулись Московской городской Думы. Еще в апреле 2020 года были внесены изменения, позволяющие парламентариям проводить заседания в дистанционной форме. В документе даже был отмечено отдельное понятие «дистанционное заседание Думы», проводят их, в соответствии с этим документом, с использованием «средств видеоконференц-связи» и «системы управления информацией Думы». Также в регламенте написано, что информация о проведении дистанционного заседания Думы незамедлительно направляется депутатам Думы и размещается на официальном сайте Думы в сети «Интернет».

Нельзя не отметить и еще один символ информационной трансформации, вызванной эпидемией коронавирусной инфекции - дистанционное электронное голосование. Хотя эксперименты по внедрению ДЭГ проводились и ранее, тем не менее именно в начале пандемии, в мае 2020 года вступил в силу законопроект «О проведении эксперимента по организации и осуществлению дистанционного электронного голосования в городе федерального значения Москве».

В рамках эксперимента, как раз таки и прошли выборы с использованием дистанционного электронного голосования на выборах в органы государственной власти, органы местного самоуправления [2]. Можно 
сказать, что дистанционное электронное голосование из-за административных ограничений, связанных с эпидемией COVID-19, преобразовалось из тестового формата в привычную электоральную процедуру. Есть мнение, что коронавирус стал лишь официальной причиной для широкого и ускоренного внедрения информационных технологий в процесс голосования. В то же время это никак не отменяет самого факта, что пандемия оказала сильное влияния на информационную трансформацию в этой cфepe.

Таким образом, происходящие процессы информационной трансформации государственной власти и, в частности местного самоуправления объективно ускорились в связи с пандемией коронавируса COVID-19. Прежние тренды на усиление роли электронных систем в местном самоуправлении усилились, сформировалась новая правовая база в муниципальных образованиях, позволяющая теперь часть важных процессов проводить в дистанционной форме. Пандемия коронавируса укрепила и без того сильный вектор развития системы МСУ на пути к цифровизации и повсеместного использования электронного участия, а также обосновала преобразование дистанционного электронного голосования из тестового формата в привычную электоральную процедуру.

\section{Литература:}

1. Федеральный закон от 06.10.2003 № 131-Ф3 (ред. от 03.08.2018) «Об общих принципах организации местного самоуправления в Российской Федерации» (с изм. и доп., вступ. в силу с 19.08.2018) // Российская газета. 2003. 08 октября (№ 202).

2. Федеральный закон от 23.05.2020 № 152-Ф3 «О проведении эксперимента по организации и осуществлению дистанционного электронного голосования в городе федерального значения Москве» // Российская газета. 2020. 25 мая (№ 110).

3. Решение Совета городского округа город Уфа Республики Башкортостан от 23 июня 2020 года № 62/33 «О внесении изменений в Положение о публичных слушаниях в городском округе город Уфа Республики Башкортостан» // Официальный сайт Совета городского округа город Уфа Республики Башкортостан. URL: http://gorsovet-ufa.ru/resheniyanew/?SECTION_ID=401\&ELEMENT_ $\mathrm{ID}=10796$.

4. Решение Совета городского округа город Уфа Республики Башкортостан от 30 сентября 2020 года № 66/2 «О внесении изменений в Устав городского округа город Уфа Республики Башкортостан» // Официальный сайт Совета городского округа город Уфа Республики Башкортостан. URL: http://gorsovet-ufa.ru/resheniyanew/ ?SECTION_ID=416 \&ELEMENT_ID=11114. 
5. Решение Совета городского округа г. Уфа РБ от 30.06.2021 № 83/15 «О внесении изменений в Регламент Совета городского округа город Уфа Республики Башкортостан» // Официальный сайт Совета городского округа город Уфа Республики Башкортостан. URL: https://gorsovet-ufa.ru/resheniyanew/?SECTION_ID=452\& ELEMENT_ $\mathrm{ID}=12053$.

6. Информатизация общества: социологический анализ: коллективнаямонография / отв. ред. А.Ю. Нагорнова. Ульяновск: Зебра, 2016.

7. Жизнь онлайн: потребление, пользование, развлечения. Аналитический обзор // ВЦИОМ. 16.12.2020. URL: https://wciom.ru/analyticalreviews/analiticheskii-obzor/zhizn-onlain-potreblenie-polzovanierazvlechenija.

8. Михайленок O.M., Малышева Г.А. Пандемия COVID-19 - новый этап цифровой трансформации общества // Социальные и гуманитарные знания. 2021. Т. 7. № 1. С. 28-39.

9. Чугунов А.В. Взаимодействие граждан с властью как канал обратной связи в институциональной среде электронного участия // Власть. 2017. № 10. URL: https://cyberleninka.ru/article/n/ vzaimodeystviegrazhdan-s-vlastyu-kak-kanal-obratnoy-svyazi-v-institutsionalnoy-sredeelektronnogo-uchastiya.

10. Волков Д., Гончаров С. Российский медиаландшафт - 2020: телевидение, интернет, социальные сети и мессенджеры // Вестник общественного мнения. Данные. Анализ. Дискуссии. 2020. № 1-2 (130). С. 141147.

(C) Котельников В.М., Ямалова Э.Н., 2021 г. 